\title{
An investigation into possibilities for implementation of a virtual community of practice delivered via a mobile social network for rural community media in the Eastern Cape, South Africa
}

\begin{tabular}{|c|c|}
\hline \multicolumn{2}{|c|}{$\begin{array}{l}\text { Authors: } \\
\text { Oliva Muwanga-Zake }{ }^{1} \\
\text { Marlien Herselman }{ }^{1}\end{array}$} \\
\hline \multicolumn{2}{|c|}{$\begin{array}{l}\text { Affiliations: } \\
{ }^{1} \text { Department of Information } \\
\text { Systems, University of Fort } \\
\text { Hare, South Africa }\end{array}$} \\
\hline \multicolumn{2}{|c|}{$\begin{array}{l}\text { Corresponding author: } \\
\text { Oliva Muwanga-Zake, } \\
\text { muwango@eskom.co.za }\end{array}$} \\
\hline \multicolumn{2}{|c|}{$\begin{array}{l}\text { Dates: } \\
\text { Received: } 04 \text { Dec. } 2015 \\
\text { Accepted: } 21 \text { Sept. } 2016 \\
\text { Published: } 17 \text { Mar. } 2017\end{array}$} \\
\hline \multicolumn{2}{|c|}{$\begin{array}{l}\text { How to cite this article: } \\
\text { Muwanga-Zake, O. \& } \\
\text { Herselman, M., 2017, 'An } \\
\text { investigation into possibilities } \\
\text { for implementation of a } \\
\text { virtual community of practice } \\
\text { delivered via a mobile social } \\
\text { network for rural community } \\
\text { media in the Eastern Cape, } \\
\text { South Africa', South African } \\
\text { Journal of Information } \\
\text { Management 19(1), a730. } \\
\text { https://doi.org/10.4102/ } \\
\text { sajim.v19i1.730 }\end{array}$} \\
\hline \multicolumn{2}{|c|}{$\begin{array}{l}\text { Copyright: } \\
\text { (C) 2017. The Authors. } \\
\text { Licensee: AOSIS. This } \\
\text { is licensed under the } \\
\text { Creative Commons } \\
\text { Attribution License. }\end{array}$} \\
\hline \multicolumn{2}{|l|}{ Read online: } \\
\hline 口乎: & $\begin{array}{l}\text { Scan this QR } \\
\text { code with your } \\
\text { smart phone or } \\
\text { mobile device } \\
\text { to read online. }\end{array}$ \\
\hline
\end{tabular}

\begin{abstract}
Background: The purpose of this article is to provide an overview of how a virtual community of practice can be delivered via a mobile social networking framework to support rural community media in the Eastern Cape Province of South Africa.

Objectives: The article presents the results of a study conducted to ascertain the possibilities of utilising mobile social networking as a means to provide access to required information and knowledge to rural community media through creation of a virtual community of practice. Improving the operational effectiveness of rural community media as a component of the rural community communication process would serve to improve the entire rural community communication process as well, making them more effective tools for availing relevant news and information to rural communities and reflecting the realities of rural communities to their broader environment.

Method: The study was conducted on rural community media small micro and medium enterprises (SMMEs) in the Eastern Cape Province of South Africa. The study applied an interpretive research philosophy, qualitative research design and multiple-case study approach. Primary data were collected through semi-structured interviews supported by a questionnaire, with secondary data collected via literature review, observation and documentation analysis.
\end{abstract}

Results: Findings were that rural community media do make use of social media and mobile devices in operating their business, require access to generic and domain specific support services and actively engage their peers and stakeholders in this respect, although no formalised structure existed. The authors' recommendation is to create a formalised virtual community of practice through the establishment of a mobile social network.

Conclusion: Because of the fact that rural community SMMEs already utilise mobile devices and social media to operate their businesses, development of a solution based on a mobile social networking platform could be a useful tool in providing support to these SMMEs.

\section{Introduction}

The International Fund for Agricultural Development (IFAD 2011:7) states that in developing countries entrepreneurs and their micro and small-scale enterprises (MSEs) are recognised as 'necessary engines for achieving national development goals such as economic growth, poverty alleviation, employment and wealth creation, leading to a more equitable distribution of income and increased productivity...'. MSEs have become a major concern in an attempt to accelerate growth rates in low-income countries such as Africa (IFAD 2011). These enterprises are faced with unique problems that affect their growth, reducing their ability to contribute effectively to economic development (IFAD 2011).

Baumgartner, Schulz and Seidl (2013) conducted a study that concluded that entrepreneurship in rural areas may not be a distinctive 'rural' phenomenon, rather 'rural' is conceptualised as specific attributes measured by specific indicators. As a result, rural entrepreneurs are seen not as following a process unique to them but rather operating within a distinctive context or environment. Rural areas are generally afflicted by the twin economic ills of poverty and unemployment, with human resources typically employed below their productive potential (The Eastern Cape Development Corporation [ECDC] 2015).

The very nature of the rural environment itself inhibits the existence and/or cultivation of precursors that could subvert poverty and encourage socio-economic development 
(Duncombe 1999). Based on this, it is not surprising that entrepreneurs in rural areas face a host of difficulties (Horn \& Harvey 1998). Because these businesses are small and isolated, the people and information base needed to provide expert support for critical decisions and functions do not exist internally or externally within the rural location; furthermore, the needs of the enterprise are continuing, not one-time, and if the enterprise is successful, the needs grow (Horn \& Harvey 1998).

Rural areas typically share a number of common characteristics that constrain rural entrepreneurial operation, these comprise the following (Heeks 2009):

- lack of access to relevant information and knowledge

- lack of empowerment

- lack of participation and inclusion

- poor communication and information flow.

\section{Rural community media}

The authors have specifically scoped the research that informs this paper to focus on rural community media as a specialised sub-segment of entrepreneurs operating in rural areas. The reasons for this decision were in part because of the effect and impact of community media on socio-economic development because of the role they play in enabling access to information and knowledge and giving a voice to poor and isolated communities.

Opubor (2000) states that amongst other things, human communities are built on the exchange of initiatives, information and meaning in the process of defining, creating and maintaining a collective identity in the interests of survival within a specific geographical and/or cultural space. A community thus creates, and is also created by, a shared communication system, which comprises communication roles, needs and resources available to individuals and subgroups within this shared space (Opubor 2000). 'Community media should be viewed then as an element of a community communication system' ... serving as instruments for role performance and resource utilisation in response to the communication needs of individuals and institutions within the community (Opubor 2000:3). In this light, improving the operational efficiency of rural community media, as an element of the rural community communication system, will also serve to ultimately improve the efficiency of the rural community communication system as a whole.

Banda (2010) states that communication via community media could serve to build a sense of community amongst citizens. Banda (2010) further notes important implications for community media as follows:

- greater access for citizens

- more use of community voices in news stories

- the possibility of citizen ownership and operation of media platforms

- greater opportunity to experiment with more participatory approaches to communication.
South African rural community media face specific challenges based on the broader South African media context as well as the rural context within which they operate. In assessing domain specific rural community media constraints and challenges, the Print and Digital Media Transformation Task Team (PDMTT 2013) identifies major rural community media challenges as being related to the news production value chain, which comprises the following broad steps:

- create and manage content

- build awareness

- distribute

- monetise.

Uncovering means with which to support rural community media in effectively navigating their rural environment as well as accessing domain specific information and knowledge would facilitate improved operational efficiency and sustainability of these rural-based small micro and medium enterprises (SMMEs). Assessment of means to provide support to rural community media via access to relevant information and knowledge accessible through an appropriate technology based platform could aid in the development of a framework that would support rural community media through facilitating access to information and knowledge that could positively impact their operational efficiency.

\section{Knowledge sharing and communities of practice}

Communities of practice are identified as a possible means to assist rural community media with accessing relevant information and knowledge. Karvalics (2012:2) states that the notion of communities of practice is based on the field of organisational learning and refers to interest groups that get together at work and in social settings into which newcomers can enter and learn the sociocultural practices of the community'. Karvalics (2012:2) defines a community of practice as:

a unique combination of three elements: a domain of knowledge, which defines a set of issues; a community of people who care about this domain; and the shared practice that they are developing to be effective in their domain.

Uriarte (2008) adds that communities of practice have been proven to be excellent means to share knowledge amongst people who share a common interest. However, adequate technology infrastructure is needed for the creation, organisation, sharing and application of knowledge (Uriarte 2008). Technology and the ability to use it and adapt it have become an important factor in generating and accessing the wealth, power and knowledge necessary for development (Pott 2003). Based on the above arguments, the policy implications and emphasis clearly relate to two things - knowledge transfer and investment in technology (Mansell 2012). 


\section{Mobile social networking}

Mobile social networking is identified as a possible delivery component for development of a virtual community of practice that could assist rural community media. Social networking is a technology that is currently, pervasive, accessible and easy to use (Deloitte 2012). Social networking sites are defined as web-based services that allow users to post a profile and connect to other users (Durham, Cragg \& Morrish 2009). In recent years, social media has also developed to allow for networking with professionals or same interest groups and community engagement (Durham et al. 2009). Durham et al. (2009) add that low barriers to entry allow SMMEs to utilise social media in the same ways that large enterprises do without the need for extensive resources. They (Durham et al. 2009) further advise it likely that SMMEs could benefit from social media through jointly creating value with other parties.

Social media consists of content, communities and Web 2.0 technologies (Nicholson 2011). In general, social media refers to applications that are either completely based on usergenerated content or in which user-generated content and the actions of users plays a substantial role in increasing the value of the application and/or service (Nicholson 2011). Although social media was originally a tool for friends to connect, communicate and share online, it has now also been adopted as a business tool (Durham et al. 2009). Online business presence via social media is now more a norm than an exception.

Relevant literature reports that the key purpose of social media is to engage people in one of four ways (Nicholson 2011), namely communication, collaboration, education and entertainment. The main advantages of transactions via mobile technology also apply to social media, as the former appears to be a key enabler of the latter. According to Murthy (2010), these advantages include ubiquity (available everywhere), localisation (location-based engagement), personalisation (tailored to the individual) and convenience (anytime, anywhere). Trends in social media indicate increased use by a business. It is observed by Nicholson (2011) that social media has now graduated from being a fashionable trend to a strategic tool. This has resulted in increased attention from researchers and practitioners, with the former developing skills to better utilise the technology and the latter developing models to explore business value and examine aspects of use.

This paper presents outcomes of a study conducted to ascertain whether there is opportunity to utilise mobile social media to assist rural community media SMMEs in the Eastern Cape Province of South Africa, through creation of a virtual community of practice that could facilitate improved operational efficiency.

\section{Research methodology}

This research seeks to answer the following research question: How can a framework for mobile social networking support and/or enhance rural SMME's through the creation of virtual communities of practice?

The case study conducted was scoped to focus specifically on rural community media with fieldwork conducted in the Eastern Cape Province of South Africa. The research methodology applied, is based on the Saunders, Lewis and Thornhill (2015) research onion. Saunders et al. (2015) research onion comprises multiple layers demonstrating various perspectives to be considered when designing and implementing a suitable research methodology. Their (Saunders et al. 2015) research onion compares the research processes to peeling different layers of an onion until the centre has been reached. The centre of the research process depicted by the onion is the analysis of collected data, with associated subcomponents comprising research philosophy, design, approach, data collection and analysis methods make up the research onion (Saunders et al. 2015).

The study applied an interpretive research philosophy, qualitative research design and a multiple-case study approach. Primary data collected through semi-structured interview supported by a questionnaire, with secondary data collected via literature review, observation and documentation analysis. Hermeneutics was utilised as the data analysis technique where cross-case data analysis and triangulation were applied. Additional broad factors for inclusion in the study included that selected cases operate an SMME in a rural area in the Eastern Cape Province. The study was conducted in October 2015 in the Eastern Cape Province of South Africa.

Data collection methods included interview, observation and documentation review. The researcher made use of semistructured interviews guided by a standardised questionnaire as the primary data gathering tool. Observation and document analysis were used to provide additional information. The owners of the rural community media SMMEs were interviewed, this is because of the fact that being the creator and driver of the business they would be most familiar with business operations and various constraints impacting their operational efficiency.

The author reviewed meeting minutes, business plans and the actual newspaper product. Review of the selected documentation provided a view of the manner in which the SMMEs were run, the strength of governance and management processes and the quality of the product produced as a result of these. In addition to this, the author observed the operational environment of the SMMEs to develop further understanding of the context they operate in and how it impacts them. Observation was conducted at the same time as the interviews, with pre-identified guidelines as follows:

- Which Information and Communication Technology (ICT) is used by the SMME?

- Which ICT equipment is visible?

- Which visual evidence can be viewed of management approach and/or structured operations? 
The observation process conducted (Figure 1) was as follows.

The sampling technique utilised in this research was maximum variation sampling. The rural community media SMMEs selected for inclusion in this study demonstrated variation related to years of operation, number of employees and location within the Eastern Cape, South Africa. In selecting the utilised seven cases, the researcher approached key rural community media support organisations operating within the Eastern Cape, South Africa, described the nature of the study being conducted and asked that they forward a directory of rural community media that could be included. The organisations contacted were the Media Diversity and Development Agency (MDDA), Association of Independent Publishers (AIP) and Eastern Cape Communications Forum (ECCF). All rural community media SMMEs included in this study operated within the Eastern Cape, South Africa.

This study utilised cross-case analysis (and triangulation), as different cases were analysed to identify cross-cutting issues or themes. The unit of analysis for this research was identified as the rural entrepreneurs operating as rural community media SMMEs in Eastern Cape Province, South Africa. The diagram below depicts the steps taken by the author in conducting the thematic analysis based on guidelines from Creswell (2009).

In conducting the thematic analysis (Figure 2) the author developed codes or labels to identify data that were key to answering the research question. These codes or labels were then used to collate and group data extracts for further analysis. The third step of the thematic analysis involved searching the collated or grouped data for themes. Once potential themes were identified they were checked against the data set to confirm their validity and that the themes were reflective of the data that were collected. Following the process of checking and confirming the validity of each theme the author then selected a descriptive name per theme as well as developed a definition per theme. The process concluded with a write-up of the results of the thematic analysis.

Each of the resultant themes has been discussed in detail in Table 1.

\section{Section A1: Years in operation versus size of the small micro and medium enterprise}

Analysis of data obtained from Section A of the questionnaire resulted in the observation of the above mentioned theme in the data. The author observed that while Case 2 had been in operation for the longest period amongst the cases studied, 8 years, and had a total of seven employees; Case 3 had also been in operation for a period of 8 years but had only four employees. Case 5 had been in operation for 7 years and had a total of six employees, which is equal to the number of employees held by Case 4 , which had only been in operation for a period of 2 years. Case 6 had been in operation for 5 years and had four employees, followed by Case 7 in operation for a total of 4 years with six employees and Case 1 in operation for 3 years with a total of four employees. As can be seen from the data shared above, there is no apparent correlation in the data between the number of years in operation and the number of employees, which may point to a growth challenge in the Eastern Cape rural community media space. It could be that the number of employees is likely determined by other factors such as cost of labour, funding availability or profitability of the business.

\section{Section B1: Information and Communication Technology as an enabling resource}

Section B data analysis revealed that all seven cases surveyed indicated a view that the use of ICT could positively impact their business operation by assisting with access to information and knowledge and by supporting communication. Case 1 held the view that ICT can be utilised

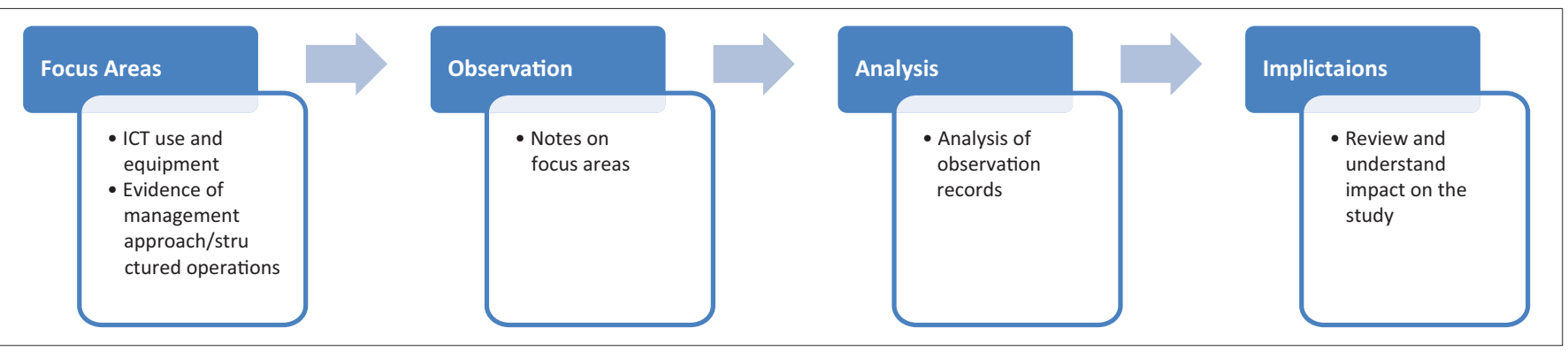

Source: Adopted from Rumo, J., 2013, Absorptive capacity and information technology adoption strategies in Kenyan SMEs, Unpublished work, University of Fort Hare FIGURE 1: Observation process.

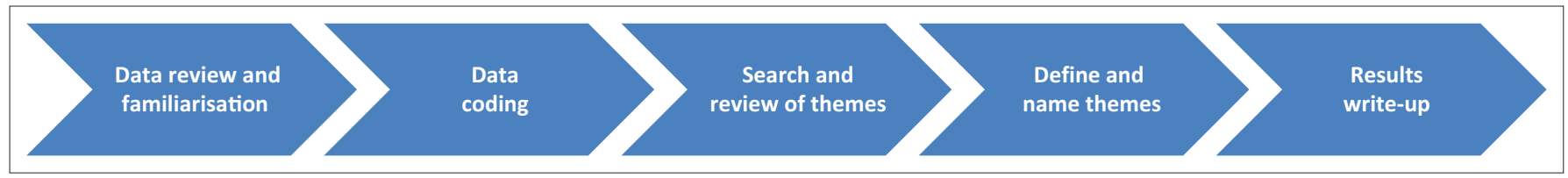

Source: Adopted from Creswell, J., 2009, Research design, Sage, Newbury Park, CA, United States

FIGURE 2: The thematic analysis process. 
TABLE 1: Research questions and questionnaire linked to possible themes.

\begin{tabular}{|c|c|c|c|c|}
\hline Section & Content & Related research sub-question & Objective & Possible themes \\
\hline A & $\begin{array}{l}\text { 1. How long have you been in operation? } \\
\text { 2. How many employees do you have? } \\
\text { 3. What town/city is your business based in? }\end{array}$ & None, background questions & Understand general background & General info \\
\hline B & $\begin{array}{l}\text { 1. Do you think ICT can facilitate engagement and } \\
\text { access to support services, information and } \\
\text { knowledge sharing in a manner that can assist } \\
\text { your business? YES/NO (circle relevant) } \\
\text { - If yes, what do you think you need in order to } \\
\text { leverage ICT to support your business? }\end{array}$ & $\begin{array}{l}\text { Sub-problem 1: What are the building } \\
\text { blocks for a mobile social networking } \\
\text { framework for SMMEs, which utilises } \\
\text { virtual communities of practice as a } \\
\text { vehicle? }\end{array}$ & $\begin{array}{l}\text { Understand views on ICT capability } \\
\text { to assist in accessing required } \\
\text { resources }\end{array}$ & ICT as an enabling resource \\
\hline C & $\begin{array}{l}\text { 1. Do you need business advice/support? YES/NO } \\
\text { (circle relevant) } \\
\text { 2. If yes, what areas do you require support in } \\
\text { (Please tick all that apply)? } \\
\text { - Financial Management/Funding Support } \\
\text { - Business Planning and Management } \\
\text { - Internal Resource Management } \\
\text { - Training (Writing/Markess } \\
\text { - Stakeholder Engagement and Support } \\
\text { 3. What are the most challenging issues impacting } \\
\text { your business right now? }\end{array}$ & $\begin{array}{l}\text { Sub-problem 2: What are the } \\
\text { knowledge sharing needs of rural } \\
\text { SMMEs? }\end{array}$ & $\begin{array}{l}\text { Understand rural community } \\
\text { media support requirements }\end{array}$ & $\begin{array}{l}\text { Support requirements trends or } \\
\text { key areas }\end{array}$ \\
\hline D & $\begin{array}{l}\text { 1. Do you engage other community media or } \\
\text { community media stakeholders for advice/ } \\
\text { support? YES/NO (circle relevant) } \\
\text { - If yes, how often and what areas do you } \\
\text { engage in for advice/support? } \\
\text { 2. Do you feel that the advice/support/resources } \\
\text { you need to thrive as a business are readily } \\
\text { available/accessible? YES/NO (circle relevant) } \\
\text { - If no, why, what are the issues/challenges } \\
\text { impacting you in this respect? }\end{array}$ & $\begin{array}{l}\text { Sub-problem 3: How can a virtual } \\
\text { community of practice facilitate } \\
\text { knowledge sharing, improved } \\
\text { business support and socio- } \\
\text { economic impact for rural SMMEs? }\end{array}$ & $\begin{array}{l}\text { Understand stakeholder engagement } \\
\text { practices and motives for initiating } \\
\text { engagement }\end{array}$ & $\begin{array}{l}\text { Stakeholder engagement } \\
\text { practices and motives }\end{array}$ \\
\hline E & $\begin{array}{l}\text { 1. Do you make use of your cell phone for your } \\
\text { business? YES/NO (circle relevant) } \\
\text { - If yes how do you use your cell phone to } \\
\text { facilitate your business (phone calls, SMS etc.)? } \\
\text { 2. Do you access the Internet for business } \\
\text { purposes? YES/NO (circle relevant) } \\
\text { - If yes, how often do you access the Internet for } \\
\text { business purposes? } \\
\text { What challenges do you experience around } \\
\text { Internet access, if any? }\end{array}$ & $\begin{array}{l}\text { Sub-problem 4: How do SMME's } \\
\text { make use of mobile social networking } \\
\text { to enhance their businesses? }\end{array}$ & $\begin{array}{l}\text { Understand the use of mobile } \\
\text { devices and Internet access as well as } \\
\text { challenges in accessing the Internet }\end{array}$ & $\begin{array}{l}\text { Mobile and Internet use for } \\
\text { business. challenges in Internet } \\
\text { access }\end{array}$ \\
\hline $\mathrm{F}$ & $\begin{array}{l}\text { 1. Do you make use of social media for business } \\
\text { purposes? YES/NO (circle relevant) } \\
\text { - If yes, which applications/sites do you make } \\
\text { use of (Please tick all that apply)? } \\
\text { - WhatsApp } \\
\text { - MixIT } \\
\text { - Lacebook } \\
\text { - Twitter } \\
\text { - Instagram } \\
\text { - Pinterest } \\
\text { - Other (please specify) } \\
\text { business purposes (advertising, networking)? } \\
\text { - If no, why not? }\end{array}$ & $\begin{array}{l}\text { Sub-problem 5: What different social } \\
\text { networking possibilities exist that can } \\
\text { support SMME's? }\end{array}$ & $\begin{array}{l}\text { Understanding use of social media } \\
\text { for business }\end{array}$ & Use of social media for business \\
\hline
\end{tabular}

to provide access to support services, information and facilitate knowledge sharing but indicated suitable connectivity and hardware as requirements for this to happen after having experienced issues with connectivity regardless of utilising a high-speed ADSL line. Cases 2, 4 and 6 concurred that ICT can act as an enabling resource for rural community media but indicated no additional requirements for this to happen. While Case 3's views were aligned with those of Case 1 and 2 regarding the usefulness of ICTs for business, they indicated a need for training/engagement on how this can be done. Case 5 highlighted the concern of old PCs and technology being a possible impediment to fully realising the benefit of ICT application in the business context, and Case 7 shared the specific concern of the lack of a business website as a challenge to fully realising the benefits of ICT for business. It is encouraging that rural business already has an appreciation for how ICTs could be useful enabling resources for business. Some are more aware than others regarding impediments of use in rural or peri-urban settings, such as connectivity issues, aging equipment and training requirements. These issues could likely be assisted through knowledge sharing and support with stakeholders who could contribute to resolving the situation.

\section{Section C1: Internal business process support requirements}

Analysis of Section $C$ data revealed that six of the seven cases studied indicated that they could benefit and were in need of business advice and support. Assistance with internal business processes was a cross-cutting theme in the data. Internal business process support had to do with support for certain segments of the news production value chain. A number of internal business processes were identified as areas where support is required. Case 1 specifically mentioned a requirement for support with funding, advertising and marketing. Case 2 concurred with Case 1 on advertising as 
an area that required additional support but added training as an additional requirement. Although Case 3 stated that they did not require additional business advice and support, they did specify a need for graphic design services to assist with the layout of their paper. Case 4 specified requirements for sales, production and distribution support, while Case 5 specified funding, business planning and management, sustainability and advertising as areas where additional support was required. Case 6 concurred with Case 1, specifying marketing and advertising as areas where additional support was required. Case 7 highlighted the need for financial management and funding, admin, sales and marketing support. Case 4 specifically stated that the structure of the market was an impediment to community media, specifically the ability to secure advertising. A specific query/concern shared by Case 4 was regarding what informs advertising buying decisions, noting a bias for established and mainstream media. Case 4 further stated that distribution channels were inaccessible and operated like a cartel with mainstream media either in tight relationships with or outright owning print and distribution channels. Crosscutting areas mentioned more than once were advertising, marketing, funding and financial management and sales. Means with which to ensure access to support for these specific areas would be a useful and required component for a proposed solution.

\section{Section C2: Structured operations and quality of product}

An item related to internal business process, governance was identified as an element that appeared to impact ultimate quality of the end product. This theme was uncovered through assessment of the observation data and document analysis. There appeared to be correlation between cases with more structured internal business operations and a superior end product. Observation of Case 1 offices revealed a very neat and organised office area in an open-plan office, all documents were neatly filed and labelled with documentation analysis revealing regular meetings with employees and detailed tracking of minutes and action items. A detailed and comprehensive business plan that had been recently updated and a good quality product (well structured, good language and/or grammar, a number of adverts) were also observed at Case 1, serving as evidence of a good management and operating structure in place. Case 3 observations revealed a relatively neat office environment and a product of relatively good quality in terms of structure, average language and grammar but few adverts. Improvement opportunity in operations could be viewed at Case 3 as there was no evidence of regular office meetings or a comprehensive business plan; however, documentation analysis revealed periodic meetings taking place irregularly together with a high-level planning document, not detailed enough to serve as a business plan but indicative of some level of planning taking place with which to guide operational activities. Case 4 observations revealed a neat and orderly environment, access to meeting minute's revealed regular meetings with staff, with copies of their product revealing good structure, language and grammar and fair spread of adverts. Case 5 observation revealed a small, relatively untidy office space (may have been because of size), review of their product revealed relatively small newspaper in terms of number of pages and content as compared to others, not many adverts and poor grammar/structure. Case 7 observation revealed a slightly disorganised office environment, the newspaper product was relatively small and of poor quality (poor grammar and structure, with no adverts). As can be seen from the above, the data analysed suggest that rural community media could benefit from a more structured environment with appropriate governance to direct operations, given the perceived positive correlation between this and a higher quality end product.

\section{Section D1: Stakeholder engagement}

Analysis of Section D data indicated that all cases confirmed regular engagement with their stakeholders. Case 1 indicated that they engage their peers and stakeholders at least monthly for advice and support, identifying politics within the space and cartel like behaviour both by mainstream media and more established community media as challenges impacting them. Case 2 and Case 3 specified membership of the Eastern Cape Community Print Media (ECCPM), with Case 2 advising that though established this body is yet to gain traction. The AIP and MDDA were also mentioned by Case 2 as bodies approached for support. Case 4 specifically indicated membership of the AIP and involvement in stateled engagement initiatives, advising that the department of communications was active in engaging community media and creating opportunities for them to interact with the government and their peers and stakeholders to address the various issues impacting this space. Case 5 specifically indicated membership of a community media hub in the Eastern Cape, indicating that it was however not yet strong enough to effectively protect the interests of community media. Cases 6 and 7 made specific mention of AIP membership. The data revealed that all cases see stakeholder engagement as crucial for their business operation, and also that a number of cases are members of the same associations. This shows that the concept of community and working together as well as attempting to learn through engagement already exists within this environment; means to further enhance this would prove beneficial.

\section{Section D2: Accessible versus inaccessible support services}

There were mixed views on how accessible support services were, with four of the seven cases indicating that support services were not easily accessible. Cases 1, 2, 4 and 6 indicated that support is not easily accessible within the rural community media space, while Cases 3, 5 and 7 indicated the opposite. Case 2 added that obtaining access to certain support services and generally slow progress in the space were additional impediments. Case 2 further advised that they are also trying to leverage government for support/ assistance and shared the concern that community media is dying because of lack of support, with a number of SMMEs having folded as a result of this. Case 6 further added that communication in the rural community media space was 
a major issue. The almost equal split between cases indicating ease of access to support services and cases indicating the opposite suggests that some of the cases surveyed may have knowledge or access to info that the others do not. The creation of an environment that facilitates knowledge and information sharing amongst rural community media may serve to remedy the situation.

\section{Section E1: Cell phones and Internet use for business}

All cases indicated that they made use of cell phones and accessed the Internet for business purposes. All cases specified use of cell phones (both phone and SMS services) as a business tool on a daily basis. It was also specified by all cases that the Internet is accessed daily for business purposes. Case 1 indicated cost and network issues as constraints they faced on a daily basis in this regard. Case 3 indicated a weekly cost of R100 for data bundles as a high cost given their limited funds, with their main issue regarding the Internet use being that it is expensive. Cases 4 and 5 echoed the concerns raised by Case 3 by sharing high-data costs as a concern. Case 7 specifically raised their concern regarding lack of a business website. Both Cases 2 and 6 did not indicate any specific challenges regarding the use of the Internet and cell phones for business purposes. The confirmed use of mobile devices and the Internet by all cases indicates that these may be good delivery mediums for facilitating access to required support services. Support may be required regarding the cost of access to the Internet.

\section{Section F1: Use of social media to support business operations}

All cases indicated the use of social media to support their business operations. The most utilised social media application was Facebook, followed by WhatsApp, Twitter and LinkedIn. Of specific interest is that while Facebook was used to engage externally, WhatsApp was used for internal engagement. Case 1 makes use of WhatsApp, Facebook, Twitter and LinkedIn for business purposes. WhatsApp to co-ordinate work internally and engage team members and Facebook, Twitter and LinkedIn to engage their customers and other stakeholders on their product. Case 2 makes use of WhatsApp for business purposes and also advised that they are in the process of setting up a Facebook page but are illiterate when it comes to such things and require training and support in this respect. Case 3 makes use of Facebook for business purposes and has employed a resource specifically to assist them with leveraging Facebook as a business tool. Case 4 makes use of Facebook and WhatsApp for business purposes, with Facebook utilised mainly to engage their customers and WhatsApp for co-ordinating internal operations. Case 5 makes use of Facebook and Twitter for business purposes and specifically mentioned attendance of a social media course via AIP to assist them in leveraging social media for their business. Cases 6 and 7 make use of Facebook for business purposes. Once again confirmed the use of social media for business purposes bodes well for the development of a social media-based framework in support of improved rural community media operational efficiency.

\section{Research findings}

On an average, the SMMEs surveyed were in operation for 5 years, with an average of five employees. All seven cases ( $n=37$ participants) interviewed and surveyed held the view that ICTs can facilitate access to support services, information and knowledge sharing to the benefit of their businesses. These results are depicted graphically in Figures 3 and 4.

Eighty-six percent of the cases surveying indicated a need for business support and advice. Specific support areas are depicted graphically in Figures 5 and 6.

The most challenging business areas were identified as follows: Advertising/marketing (Internal Business Process),

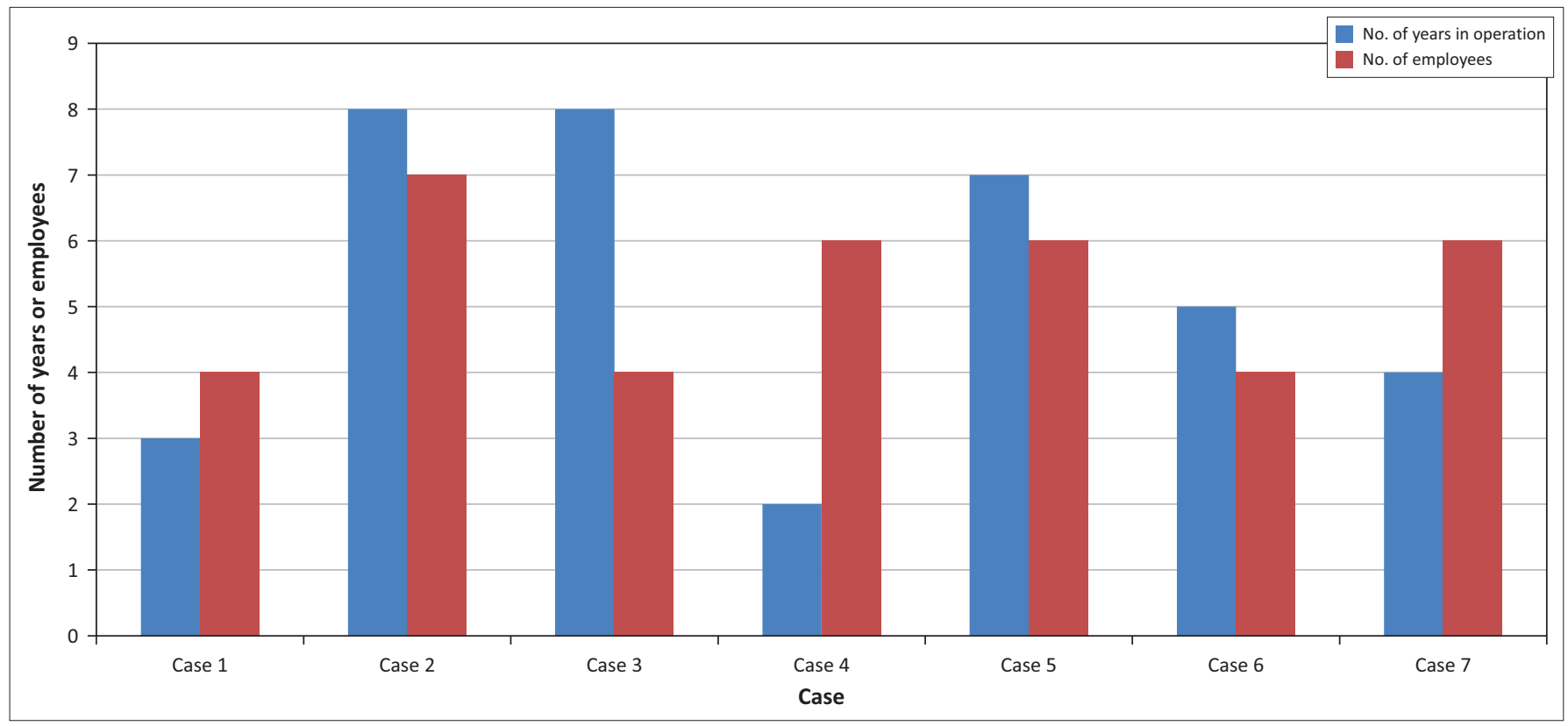

FIGURE 3: Case demographics. 
Finance (Funding/Financial Management), Production and Distribution (Internal Business Process), Sustainability (Funding), Marketing (Internal Business Process) and Administration (Internal Business Process).

Hundred percent of the cases surveyed confirmed that they engage their peers and other community media stakeholders for advice and support regularly, with $57 \%$ indicating the support is not readily accessible. This depicted graphically in Figure 7 and 8.

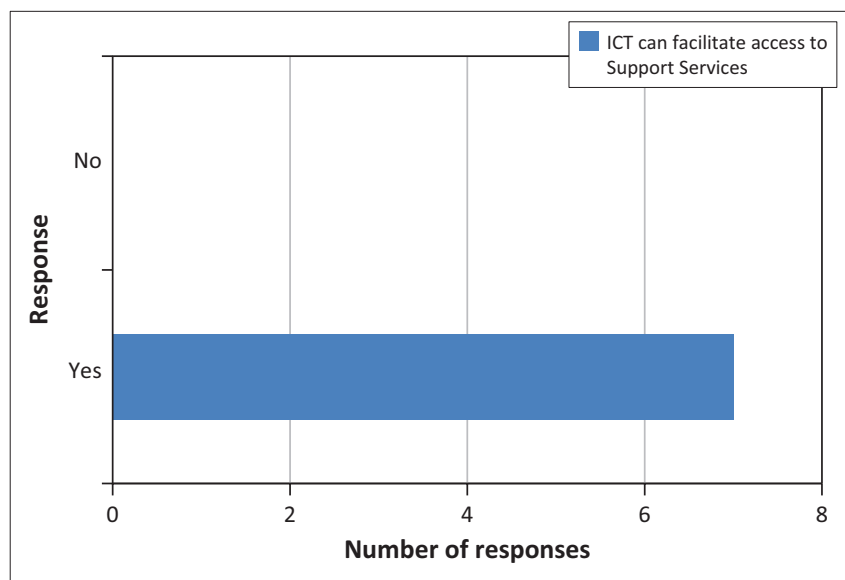

FIGURE 4: Information and Communication Technology use to access support services.

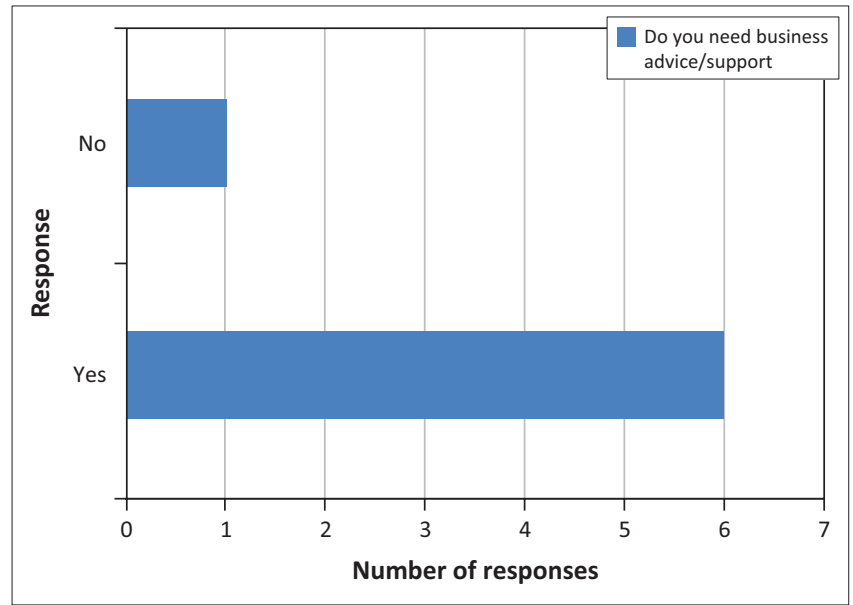

FIGURE 5: Access to business advice and support.

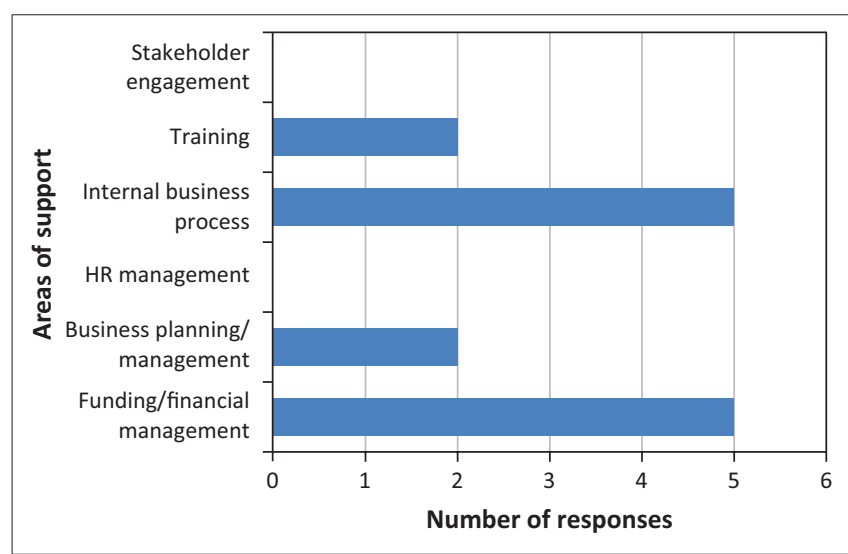

FIGURE 6: Areas for required support.
Hundred percent of the cases surveyed indicated that they made use of their cell phones and the Internet on a daily basis to operate their business. All cases surveyed made use of social media for business purposes. This is depicted graphically in Figure 9 and 10.

It can also be seen from the above that WhatsApp, Twitter and Facebook were the popular choices of social media amongst the cases surveyed. WhatsApp was mainly used to assist with internal operations and team engagement,

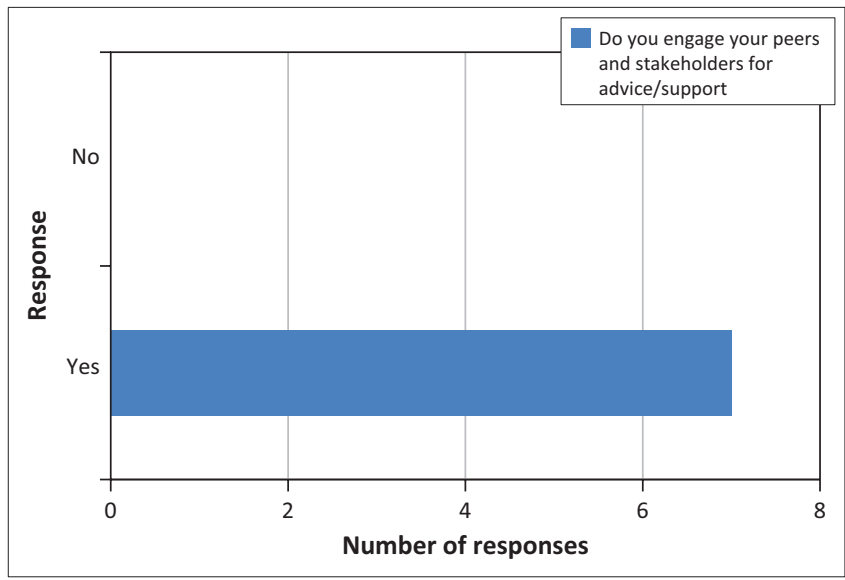

FIGURE 7: Case engagement of peers and stakeholders.

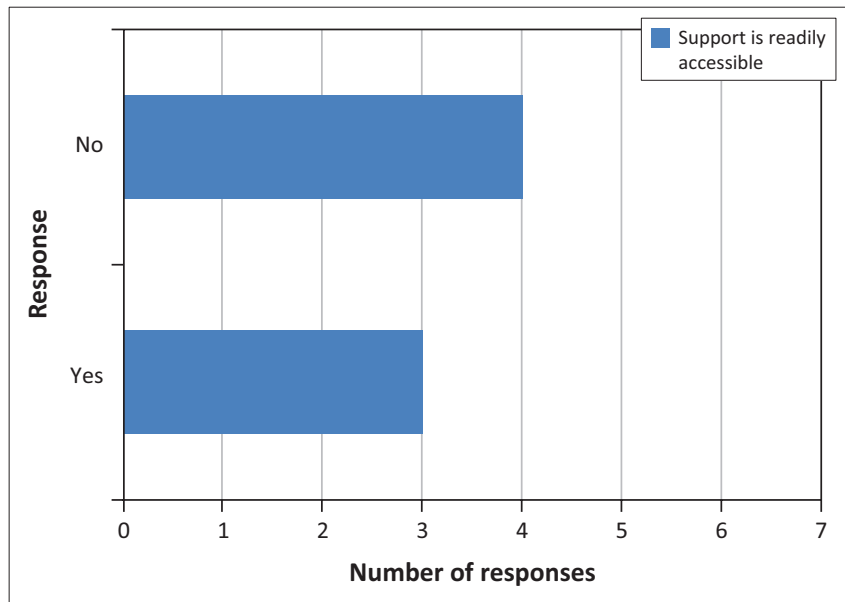

FIGURE 8: Availability of support.

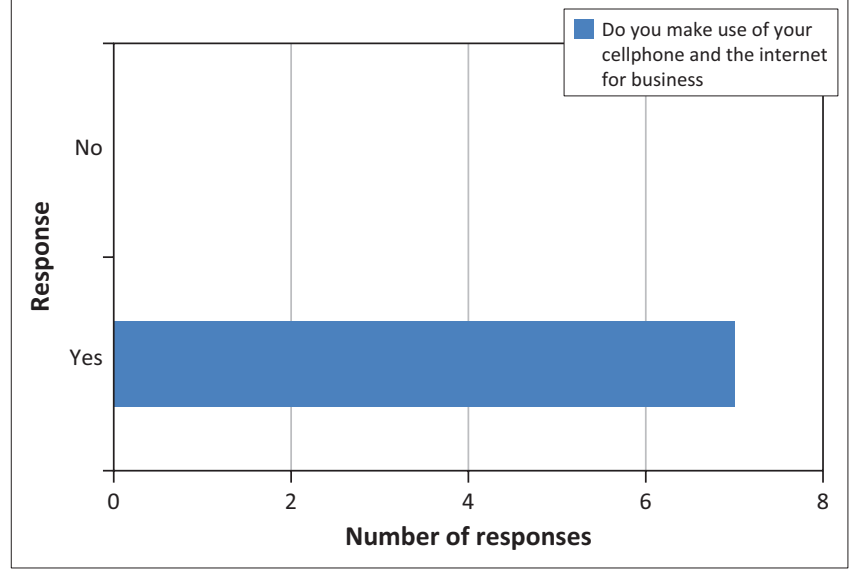

FIGURE 9: Use of cell phone and Internet for business. 


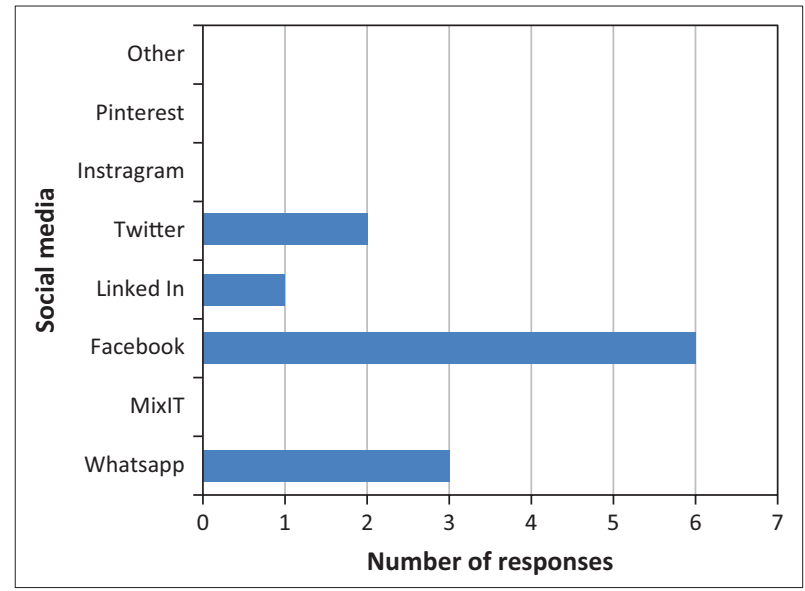

FIGURE 10: Use of social media for business.

while Facebook and Twitter were used to engage their consumers and market their product.

It was found that a virtual community of practice is a suitable vehicle for the provision of business support and advice. This is because of the fact that although the rural community media surveyed already made use of social networking and social media to enhance their business, they also access the Internet regularly and utilise their mobile devices regularly while conducting business. It was also found that there is a need for specific business support services and advice in the rural community media space in order to improve the efficiency and sustainability of these organisations.

It was concluded that the nature of the rural location generally impacted rural community media negatively because of the relative isolation and lack of support perceived by businesses operating in the area. This highlighted the need for developing means to address this issue and contribute to facilitating sustainability and growth of these businesses.

This research culminated in the development of the Rural Community Media Mobile Social Networking Framework. High-level components of the framework supported by the field work and literature include:

- Rural community media community of practice elements and/or considerations

- Rural community media business model elements and/ or considerations

- Mobile social networking technology elements and/or considerations

The Rural Community Media Mobile Social Networking Framework which incorporates all the elements found in the research as necessary for the creation of a virtual community of practice, based on a mobile social networking platform, would serve to assist community media and answer the main research question as presented in the Research Methodology component of this article.

\section{Conclusion and recommendations}

The following conclusions can be drawn from the case and expert review findings:

- There is no obvious correlation between number of years in operation and number of employees indicating that there may be a challenge with business growth if an increased number of employees are seen as an indicator

- There is a view that ICT can facilitate access to support services, information and knowledge sharing

- Additional business advice and/or support is required. Internal business process (sales, marketing, advertising, distribution and production) and funding are raised by the majority of cases surveyed as specific areas where support is required, followed by training and business planning and/or management

- All cases engage their peers and stakeholders regularly for advice and support

- There are mixed views on how accessible support in the environment is with $57 \%$ indicating the view that support is not readily accessible

- All cases make use of cell phones and the Internet for business purposes; cost of data was raised as an impediment

- All cases make use of social media for business with Facebook leading, followed by WhatsApp, Twitter and LinkedIn. Of note is the use of Facebook and the like for external engagement versus the use of WhatsApp for internal engagement.

Community media seem to already attempt to collaborate and share information; therefore, an ICT platform could further enable this practice. It was found that a virtual community of practice is a suitable vehicle for the provision of business support and advice. This is because of the fact that rural community media surveyed already make use of social networking and social media to enhance their business, and they also access the Internet regularly and utilise their mobile devices regularly while conducting business. It was also found that there is a need for specific business support services and advice in the rural community media space to improve the efficiency and sustainability of these organisations. The development of a framework that could guide creation of a virtual community of practice enabled by a mobile social network would add value to the rural community media space.

\section{Acknowledgements Competing interests}

The authors declare that they have no financial or personal relationships which may have inappropriately influenced them in writing this article.

\section{Authors' contributions}

O.M.Z., a student at the time, conducted the research. M.H. supervised the research project. 


\section{References}

Banda, F., 2010, Citizen journalism and democracy in Africa, viewed 30 October 2015 from http://www.highwayafrica.com

Baumgartner, D., Schulz, T. \& Seidl, I., 2013, 'Quantifying entrepreneurship and its impact on local economic performance: A spatial assessment in rural Switzerland', Entrepreneurship and Rural Development 25, 222-250. https://doi.org/10.1080/0 8985626.2012 .710266

Creswell, J., 2009, Research design, Sage, Newbury Park, CA, United States.

Deloitte, 2012, Social media in Africa, viewed 10 July 2014, from https://ofti.org/wpcontent/uploads/2012/10/Deloitte_Social-Media-Report_FINAL_20120709.pdf

Duncombe, R., 1999, The role of information and communication technology for small, medium and micro enterprise development in Botswana, viewed 11 January 2012, from http://www.man.ac.uk/idpm

Durham, R., Cragg, P. \& Morrish, S., 2009, Creating value: An SME and social media viewed 28 June 2012, from http://www.pacis-net.org/file/2011/PACIS2011-043. pdf

Heeks, R., 2009, The ICT4D 2.0 manifesto: Where next for ICTS and international development? viewed 12 August 2012, from http://www.sed.manchester.ac.uk/ idpm/research/publications/wp/di/index.htm

Horn, R. \& Harvey, G., 1998, 'The rural entrepreneurial venture: Creating the virtua mega firm', Journal of Business Venturing 13, 257-274. https://dx.doi. org/10.1016/S0883-9026(97)00012-8

Karvalics, L., 2012, Transcending knowledge management, shaping knowledge governance, viewed 13 July 2015, from http://basepub.dauphine.fr/bitstream/ handle/123456789/9769/InTech-Transcending_knowledge_management shaping knowledge governance.Pdf?sequence=1
Mansell, R., 2012, ICTs, discourse and knowledge societies: Implications for policy and practice, Intellect Ltd., Bristol, viewed 07 July 2015, from http://eprints.Ise.ac. $\mathrm{uk} / 39245 /$

Murthy, G., 2010, AudienceScapes development research brief, viewed 07 March 2013, from http://www.audiencescapes.org/sites/default/files/audiencescapes briefs_mobilefutures_murthygayatri.pdf

Nicholson, H., 2011, Social media 101, viewed 07 March 2013, http://irosteveperry. pbworks.com/w/file/fetch/58059588/social\%20media\%20basics.pdf

Opubor, A., 2000, If community media is the answer, what is the question? viewed 16 April 2014, from http://unesdoc.unesco.org/images/0018/001877/187739e.pdf

Pott, A., 2003, Rural development and the flow of information. Do ICTs have a role? viewed 29 September 2004, from http://www.idd.bham.ac.uk/research/ dissertations/2002-2003/Alex\%20pott.pdf

Rumo, J., 2013, Absorptive capacity and information technology adoption strategies in Kenyan SMEs, Unpublished work, University of Fort Hare.

Saunders, M., Lewis, P. \& Thornhill, A., 2015, Research methods for business students, Pearson Education Ltd., England.

The Eastern Cape Development Corporation (ECDC), 2015, About the Eastern Cape, viewed from 10 June 2015, http://www.ecdc.co.za

The International Fund for Agricultural Development (IFAD), 2011, Promoting rural enterprise growth and development: Lessons from four projects in sub-Saharan Africa, viewed 25 March 2014, from http://www.ifad.org/pub/pa/field/2.pdf

The Print and Digital Media Transformation Task Team (PDMTT), 2013, Report on the transformation of print and digital media, viewed 29 April 2014, from http:// www.printmedia.org.za

Uriarte, F., 2008, Introduction to knowledge management, ASEAN Foundation, Jakarta, Indonesia. 